\title{
THE PERFORMANCE APPRAISAL ANALYSIS OF EMPLOYEE AT BINA MANDIRI GORONTALO FOUNDATION
}

\author{
Sitti Husna Noviana Djou ${ }^{1)}$, dan Imam Mashudi ${ }^{2}$ \\ 1,2) Universitas Bina Mandiri Gorontalo \\ E-mail: sittidjou19@gmail.com
}

The purpose of this study is: 1) to find out and analyze how the implementation of employee performance appraisal at the Bina Mandiri Gorontalo Foundation; 2) to find out what factors are hampering the implementation of employee performance appraisal at the Bina Mandiri Gorontalo Foundation.

This research uses a qualitative approach and the type of research used is descriptive qualitative. Data sources used are primary data sources and secondary data sources. Data collection techniques used are observation, interviews, and documentation. Data analysis techniques used: data collection, data reduction, data presentation, and concluding. The result of the research shows that the implementation of employee performance appraisal at the Bina Mandiri Gorontalo Foundation based on 7 (seven) performance evaluation indicators can be said to be not yet fully appropriate. Three categorized indicators are by performance appraisal, namely obedience, honesty, and cooperation. Meanwhile, the indicators of leadership, responsibility, and achievement are not appropriate because in the performance evaluation that indicators still less influential. And, the initiative is categorized as inappropriate because in the performance evaluation it does not become a benchmark in performance appraisal. The factors that hampered the implementation of performance appraisal at the Bina Mandiri Gorontalo Foundation were seen from seven factors.

Based on the results of the research five factors hinder the performance evaluation, are lack of objectivity, halo effect, Leniency, Strictness, and Personal Prejudices. While the other two factors, i.e. Central Tendency and Recent Behavior Bias is inappropriate because these two factors did not hamper the implementation of performance appraisal at the Bina Mandiri Gorontalo Foundation.

Keywords: appraisal, performance, employees

\section{INTRODUCTION}

The National Development is carried out in order to develop the Indonesian nation completely/completely. To build the Indonesian nation as a whole implies that the development of the Indonesian nation is carried out as a whole which includes both body and spirit. Meanwhile, building the whole Indonesian nation implies that a nation that is formed is not only a particular society but the entire Indonesian society without distinction of ethnicity, religion \& race. Realizing the desire of the Indonesian people to realize national development in the face of increasing competition in the era of globalization.

The era of reform and globalization competition can encourage the acceleration of transformation and improvement of the performance of the government apparatus. The government is asked to work more professionally, morally, cleanly and ethically to carry out the bureaucratic reform strategy and assist in the development and smooth running of government tasks. Bureaucratic reform is currently underway in all departments / agencies and government units both at the

Submit: Oct. $16^{\text {th }}, 2020$

Accepted: Dec. $5^{\text {th }}, 2020 \quad$ Published: Dec. $17^{\text {th }}, 2020$

Journal of Economics, Business and Administration (JEBA) - E-ISSN: 2746-1688 55 
central and regional levels to achieve national development goals.

At the central level, the government has regulated the performance of ASN which is considered to have a significant impact on the institution, career system and remuneration because Law Number 5 of 2014 has reorganized the recruitment, coaching and career development system which includes a career-ranking and filling system. high office through open promotion [9].

Talking about employees / staff seems endless. Starting from how to carry out the rationalization considering the number is too large, increasing incentives to prevent corruption and increasing productivity, which has been classified as low so far.

Apart from promotion, demotion, termination, and compensation, the function of performance appraisal is also the basis for making decisions to improve employee performance if it is deemed not in accordance with the established standards. then the leadership must discipline employees by providing instructions and directions. Performance appraisal describes the beginning of a process rather than as an end product.

The educational institutions / agencies namely the Bina Mandiri Gorontalo Foundation based on the Foundation Regulation Number: 02 / YBM / 2014 of 2014, Article 4 Paragraph 1 and Article 5 Paragraph 2 and 3 concerning duties and functions can be underlined that in an effort to achieve the objectives of the Bina Mandiri Gorontalo Foundation, it is necessary performance support by human resources or good employees in the agency. Employee performance is the work result that can be achieved by a person or group of people in an organization or agency, in accordance with their respective authorities and responsibilities in order to achieve common organizational goals.

The evaluation is a process that is systematic, directed and integrated in assessing the overall elements that exist in employees as productive workers. The purpose of the research is to be able to assess the overall work implementation and work behavior of employees in the organizational group so that it can be ensured that the entire work that has been carried out has no obstacles and if an error or deviation occurs, the work can be immediately corrected and followed up in accordance with the regulations. The purpose of the Job Implementation Assessment is to obtain things that can be used as objective considerations for employee guidance.

Based on the results of preliminary observations made by researchers that the implementation of performance appraisals at the Bina Mandiri Gorontalo Foundation has been running according to the rules made by the Foundation, it's just that there are still several problems, including: 1) the process of implementing performance appraisals is only based on one aspect, so that results on an assessment that is not based on performance but based on discipline only; 2) lack of human resources as the implementation team for performance appraisal, so that the assessment process is not optimal and the results of the assessment are more of a Central Tendency in nature; 3) time consistency has not been optimal in the implementation of performance appraisals, this has resulted in the reward and punishment program set by the Foundation; 4) there is no specific standard in terms of performance appraisal, this is necessary in order to provide a balanced assessment and according to the needs of the organization so that the performance appraisal will be used as a reference for future performance appraisal programs. Based on the background of this problem, researchers are interested in conducting research on "Analysis of the Implementation of Employee Performance Appraisal at the Bina Mandiri Gorontalo Foundation". 
Performance appraisal is an assessment that is carried out on the company's management, both employees and managers who have been doing their job [1]. The definition of performance or performance is a description of the level of achievement of the implementation of an activity program or policy in realizing the goals, objectives, vision and mission of the organization as outlined in the strategic planning of an organization. Performance can be known and measured if an individual or a group of employees has criteria or benchmarks of success standards set by the organization [5]. The assessment that is carried out will later become a meaningful input in assessing the performance carried out and further improvements can be made, or what is commonly called continuous improvement.

Performance appraisal is a formal system for examining or reviewing and evaluating the performance of a person or group. Performance is the achievement / achievement of a person with respect to the tasks assigned to him [4]. Performance can also be viewed as a combination of work results (what a person has to achieve) and competence (how one can achieve it). Performance appraisal or work performance appraisals are carried out to obtain information that is useful in making decisions related to other Human Resources (HR) manager activities, such as HR planning, withdrawal and selection, HR development, career planning and development, compensation programs, promotion, demotion, retirement, and dismissal [6].

The objectives of employee performance appraisal are divided into:

1. Objectives of past-oriented assessments:

a Controlling employee behavior, using it as an instrument of reward, punishment and threats,

b Make decisions about raises and promotions, c Placing employees to carry out certain jobs.

2. Objectives of future-oriented assessments If designed appropriately, they can:

a Helping employees better understand their roles and understand clearly their functions.

b Is an instrument to help employees understand their own strengths and weaknesses in relation to the roles and functions of the company.

c Adding togetherness between employees and appraisers so that employees have work motivation, enjoy working, and are willing to contribute a lot to the company.

d It is an instrument to provide opportunities for employees to be self-aware and self-evaluated and to set personal goals so that development is planned and selfmonitored.

e Help prepare employees to hold jobs at higher levels by improving behavior and quality for higher level positions.

f Helping various HR decisions by providing employee data members regularly [10].

The presence of employees is needed in order to provide public services to students. For this reason, employees need to be given systematic guidance through various policies and guidance instruments.

Assessment of Employee Work Implementation, elements and items of employee performance appraisal, namely: 1) work performance; 2) responsibility; 3) obedience; 4) honesty; 5) cooperation; 6) initiative; 7) leadership [10].

Performance indicators are "quantitative and qualitative measures that describe the level of achievement of a predetermined target or goal" [2].

Types of local government performance indicators include: 
1. Group input (input) is anything that is needed so that the implementation of activities can run to produce outputs. This indicator measures the amount of resources such as a budget. Human resources, equipment, materials, and other inputs needed to carry out activities,

2. Process indicators are measures of activity, both in terms of accuracy, speed, and level of accuracy of the implementation.

3. Output indicator (Output) is something that is expected to be achieved directly from an activity can be in the form of physical or non-physical. Output indicators or benchmarks are used to measure the output produced from the activity. By comparing outputs, agencies can analyze whether activities have been implemented according to plan.

4. Outcome indicators are everything that reflects the functioning of the activity outputs in the medium term (direct effect).

5. The benefit group is something that is related to the ultimate goal of implementing the activity, the benefit indicator describes the benefits obtained by the outcome indicator.

6. Group impact (impact) is an influence that is generated either positive or negative [3].

Inhibiting Factors in Performance Appraisal are: Lack of Objectivity; Halo Effect; Assessment too soft (Le-niency); The assessor is too strict (Strict-ness); Tendency to Provide Middle Value (Central Tendency); Recent Behavior Bias; Personal Bias [4].

Based on the factors that hinder the performance appraisal, the performance appraisal must be in accordance with the existing / predetermined criteria. So that the results expected by the agency / company are in accordance with the objectives to be achieved.
Performance appraisal can be divided into types based on [11]:

1. Assessment only by superiors:

a Fast and direct,

b May lead to distortion for personal reasons.

2. Assessment by line group:

a The objectivity is more accurate than if only by one's own boss,

b Individuals who are highly rated can dominate the assessment.

3. The assessment by the staff group with the combined assessment is reasonable and reasonable.

4. Assessment by committee decision:

a Extending extreme considerations,

$b$ Undermining the integrity of responsible managers.

5. The assessment is based on a field review, bringing one fixed mind into one large cross-cutting assessment.

6. Assessment by subordinates and peers:

a Somewhat subjective,

b May be used as an addition to other scoring methods.

\section{RESEARCH METHOD}

This study uses a qualitative method. The qualitative approach emphasizes the meaning, reasoning, the definition of a particular situation, examines more things related to everyday life. Qualitative research methods also seek to understand and interpret the meaning of an interaction event, human behavior in certain situations according to the researcher's own perspective [7].

The reason for the use of qualitative research methods is considered appropriate because of the suitability between the characteristics of qualitative research and the phenomenon being studied. The use of qualitative research methods is directed at describing and analyzing the implementation of the performance assessment. This research is a qualitative descriptive research type because this approach is more sensitive in capturing 
various information phenomena. Especially with regard to the focus of research, this approach can also present a holistic form. The data analysis technique is an interactive model of data analysis from miles of data analysis in qualitative research, carried out when data collection takes place, and after completing data collection within a certain period. The interactive model data analysis technique consists of four steps that must be carried out, namely data collection, data reduction, data presentation, and conclusion drawing and verification [8].

\section{FINDINGS AND DISCUSSION Implementation of Employee Performance Appraisal Work performance}

Based on the results of research conducted by researchers at the Bina Mandiri Gorontalo Foundation, the implementation of performance appraisals based on work performance indicators has been used in performance appraisal indicators, but has not yet fully worked. This is due to the absence of clear SOPs and criteria regarding performance appraisal. However, the implementation of performance appraisal is still carried out as evidenced by the existence of rewards and punishments given to employees every six months.

\section{Responsible}

Responsibility means the obligation to bear responsibility for what has happened or has been done. It is also a human understanding of behavior and actions, whether intentional or unintentional. Responsibility arises from the bottom of the heart and the desire itself, and every human being has a responsibility, because everyone is burdened with responsibilities, especially in the scope of work.

In the scope of work, of course, there are rules. In addition, the responsibilities of each employee for their job vary according to the assigned field of work. There are those who are responsible as leaders and others as subordinates. Similar to the Bina Mandiri Gorontalo Foundation, which every employee has a main function based on their position, they carry out their responsibilities in accordance with these main tasks, although there are still things that are not in accordance with the expected achievements. For example, the head of a foundation who is the highest leader does not have the authority to enter the academic process in every institution under the auspices of Yayaysan Bina Mandiri Goronta-lo. He is only responsible for making general policies, as well as organizing higher education institutions, both general and special.

However, some employees work outside of their main duties and functions, which is due to the lack of Human Resources at the Bina Mandiri Gorontalo Foundation. Therefore, their responsibilities in carrying out their main duties and functions are overlapping. It can make a job that should be the main duties to be neglected because it is not appropriate with their responsibility. the weaknesses in the system are still overlapping programs or work that cannot be separated, thus the results achieved are not optimal.

\section{Obedience}

Obeying the rules and following the policies/procedures professionally is a practical way to create an organization with good governance. Every employee who obeys the rules will become positive energy and can create a comfortable, quality, productive, effective, and efficient work environment. Now the thing that can increase employee's motivation to always obey is performance appraisals. This also applies to the Bina Mandiri Gorontalo Foundation, where each employee is appraised based on their obedience or discipline to the established rules. The performance appraisal that has been 
implemented is one of the motivations to always improve employee performance.

Besides, punishment and reward must be balanced, because the punishment and reward must go together. Both are the motivation if they are produced correctly and wisely. The punishment given will produce a deterrent effect, while the reward will have the opposite effect, namely exemplary. The reward given must be useful to the employee, and the reward must be given firmly and indiscriminately. This also applies to the Bina Mandiri Gorontalo Foundation, where rewards are given once a year to outstanding employees, namely employees who are disciplined of time and work. Meanwhile, every month several employees get punishment because they are not disciplined or obedient to the time that should enter at 8:15 a.m. and they are obliged to attend the morning roll call together. It can be concluded that reward and punishment are not balanced.

\section{Honesty}

Work honestly is highly demanded by the foundation with submitting a monthly performance report based on the regulations set by the Bina Mandiri Gorontalo Foundation. The performance report is a report on the results of a month's work appropriate with the main duties and responsibilities of each employee. Meanwhile, each activity carried out must be reported in LPJ (Accountability Report) as the employee's responsibility to the foundation. This is done sincerely by the employees, even though sometimes several factors make employees less sincere in carrying out their duties, it is because the foundation's appreciation for the work results of employees is still lacking. However, they never abuse the authority given by the foundation.

\section{Cooperation}

In Bina Mandiri Gorontalo Foundation, always prioritize cooperation by forming teamwork in completing duties. Each teamwork has different duties. For them, by working in teams all work will be more effective and efficient, and they can form relationships with other employees because of togetherness. By working together, all work will be completed more easily and quickly.

\section{Initiative}

Likewise, at the Bina Mandiri Gorontalo Foundation, which is always given the freedom to convey the ideas, and how to convey them can also be done through social media or in meetings. Usually, the employees use telegram media to communicate between employees and leaders, making it easier to work. As a follow-up, the idea was adduced in a meeting to know the results whether the idea was accepted or not because all decisions would return to the chairman of the Foundation. If the idea is accepted, it is obligatory for employees to immediately implement it.

\section{Leadership}

Not all leadership styles are suitable for application in organizational culture. Therefore, an organization can see whether a leadership style is suitable to implement in the organizational culture they follow.

One of the characteristics of good leadership is the smoothness of the delegation process. Delegation is one of the main milestones of management. By giving delegations, the work will be carried out properly without delay. Based on the facts that happened at the Bina Mandiri Gorontalo Foundation, a leader often delegates his duties to his subordinates, especially in academic matters.

However, before delegating responsibilities, the leaders should pay attention to the workload of the employees concerned, because if the excessive responsibility is then added again, the results obtained will not be as expected.

\section{The Hinder Factors of the Performance Appraisal Lack of Objectivity}


The same case at the Bina Mandiri Gorontalo Foundation, where the performance assessment is not objective or tends to be subjective because it is only seen from time discipline or employee absences. It cannot be used as a benchmark in performance appraisal. There are more important things that must be used as a reference in conducting performance appraisals. Besides, there is no clear SOP regarding objective performance appraisal so that the assessment is still unclear. If there is an SOP in the performance appraisal, the evaluation will automatically be directed, and it will become a standard reference in performance appraisal.

\section{Halo effect}

Every organization must have a clear standard of performance appraisal or SOP. However, the Bina Mandiri Gorontalo Foundation is not appropriate with the assessment standards, therefore, it still needs to be updated by adding a standard for calculating performance based on the main duties and functions. Besides, there is a need for SOPs and the establishment of a performance appraisal team. So far, performance appraisal has not been based on SPMI standards, which are often used as evaluations, namely the presence and discipline of a fingerprint. Meanwhile, the mechanism for preparing indicators is still administrative based on the main duties and functions of each employee.

\section{Leniency}

The assessment team in an organization must be able to provide objective assessments to each employee and must have clear performance appraisal standards so as not to produce too lenient assessments. The ad hok team at the Bina Mandiri Gorontalo Foundation is still not working effectively because there are indicators still not used in performance appraisals so that they are not optimal. The unclear indicators are still subjective and there is no clarity regarding the follow-up. The Ad Hok team only conveys a recapitulation of discipline, attendance and coordinates the preparation of monthly reports, however, it has not been able to assess or analyze more deeply the performance of each employee.

\section{Strictness}

Several effects occur when the appraisal is too rigorous or too critical. Several employees at the Bina Mandiri Gorontalo Foundation do not agree with the overly rigorous assessment. This causes saturation, so that, the main duties and responsibilities of each employee will not run well.

With a strict assessment, employees will feel forced to carry out their duties because they are under pressure. However, the Bina Mandiri Gorontalo Foundation has not used too much rigorous assessment, it's just that the sanctions given are too strict and do not match the rewards given. Besides the strict sanctions, discipline was also tightened, especially the discipline of time. Example: Everyday employees must enter at 08.00 am and leave at 17.00 and it is indicated by a check lock, therefore, it is clear which employees are disciplined in time and which are often breaking the rules.

\section{Central Tendency}

In an organization, giving middle grades should not be done because it cannot be used as a reference for assessing individual employees accurately, is no differences will be seen for each employee. Therefore, in performance appraisal, there must be clear SOPs so this will not happen. At the Bina Mandiri Gorontalo Foundation, there is still a tendency to give middle scores because they do not have SOPs or clear rules for performance appraisals. So far, it is still subjective. Besides, this assessment was also carried out for several reasons, one of which was persuasive communication. By providing a middle score, employees will feel that they are being treated unfairly because each employee has different duties and workloads. 


\section{Recent Behaviour Bias}

Employees at the Bina Mandiri Gorontalo Foundation very disagree with the latest behavioral bias because it can undermine the objectivity of performance appraisals. Assessment in this way can be detrimental to the employees themselves.

Performance appraisal is not only in terms of discipline, but other aspects can be used as an assessment, namely the responsibility, leadership, loyalty, personality, and others. Therefore, in implementing the performance appraisal, an SOP/flow is needed so that the assessment is clear about the aspects being assessed by the assessment team. The assessment team can assess employees based on their behavior. How are the responsibilities at work and how employee initiatives and innovations are at work?

The results of this study are supported by the theory stated that "the behavior or performance that is the last or closest to the time of the assessment will be remembered more quickly than the work behavior that has occurred for a long time. In other words, the appraisal is more likely to lead to a performance appraisal that seems closer to during the implementation process the assessment is carried out" [4]. For example, if the assessment is conducted in January, the appraiser tends to remember and then assess the employee's performance in November or December only. The implementation of the performance appraisal should cover a certain period and the performance being assessed is what is shown in that period.

\section{Personal Bias}

In the Bina Mandiri Gorontalo Foundation, personal bias assessment is one of the supporting indicators in performance appraisal because a person can determine the performance of that person. However, some employees disagree with personal bias because they think it does not reflect objectivity. Performance must be measured in terms of what is produced. So, the assessment team must have clear SOPs, therefore, the assessment is not only seen from personal bias. Performance appraisal must be seen whether the employee able to complete the work for which their responsible, can be innovative, and take initiative.

\section{CONCLUSION}

Based on the description of the research results and analysis of the indicators discussed in the research on the analysis of the implementation of employee performance appraisals at the Bina Mandiri Gorontalo Foundation, several things can be concluded as follows:

1. The implementation of employee performance appraisals at the Bina Mandiri Gorontalo Foundation based on 7 (seven) performance assessment indicators can be said to have not been fully appropriate. Three indicators are categorized according to the performance appraisal, namely obedience, honesty, and cooperation. Meanwhile, the indicators of leadership, responsibility, and achievement are not suitable because in the implementation of performance appraisal these indicators are still less influential, and initiatives are categorized as inappropriate because in the implementation of performance appraisals they do not become benchmarks in performance appraisal.

2. The hinder factors of the implementation appraisal performance at the Bina Mandiri Gorontalo Foundation are seen from seven factors. Based on the results of the research, five factors hinder the performance appraisal, namely lack of objectivity, halo effect, leniency, Strictness, and personal bias. Meanwhile, the other two factors, namely the central tendency and the recent behavior Bias are not appropriate because these two factors do not hinder the implementation of 
performance appraisal at the Bina Mandiri Gorontalo Foundation.

Researchers suggest several things to the performance appraisal team at the Bina Mandiri Gorontalo Foundation in improving employee performance appraisals, namely:

1. To improve the implementation of the performance appraisal, the assessment team must establish clear SOPs so that the assessment is objective,

2. The need for continuous socialization (at least once every three months) related to SOPs and rules to Rewards and Punishment, so, it can be understood and implemented by all human resources under the Bina Mandiri Gorontalo Foundation,

3. For the Foundation to be able to complete all institutional units so that they do not overlap and their performance is directed,

4. The concept of performance appraisal in disciplinary points must be seen based on the time of entry and exit because if there is a person who is late because there is a job that requires overtime can be a point of adding / tolerance points for tardiness,

5. Consistency in enforcing the rules based on deliberation to reach consensus and objectively,

6. Following this, the researcher attaches several suggested indicators to be considered in the Bina Mandiri Gorontalo Foundation.

\section{DAFTAR PUSTAKA}

[1] Fahmi, Irham. 2010. Manajemen Kinerja Teori dan Aplikasi. Bandung: Alfabeta.

[2] Mahmudi, (2010). Manajemen Kinerja Sektor Publik. Yogyakarta: UPP AMP YKPN,

[3] Mahsun, Muhammad. 2009. Pengukuran Kinerja Sektor Publik. Yogyakarta: BPFE,

[4] Marwansyah. 2012. Manajemen Sumber Daya Manusia. Bandung: Alfabeta,

[5] Moeheriono. 2012. Pengukuran Kinerja Berbasis Kompetensi. Jakarta: PT. Raja Grafindo Persada,

[6] Panggabean, Mutiara S, 2010. Manajemen Sumber Daya Manusia. Jakarta: Ghalia Indonesia,

[7] Pasolong, Harbani. 2010. Teori Administrasi Publik. Bandung. Alfabeta,

[8] Sugiyono. 2009.Metode Penelitian Kuantitatif, Kualitatif dan $R \& B$, Bandung: Alfabeta.

[9] Podungge, D., Mashudi, I., \& Napu, K. (2020). Analysis of Performance Assessment System Model of Civil Servants in Gorontalo Province Training and Education Agency. Journal La Sociale, 1(4), 27-32,

[10] Sedarmayanti. 2017. Sumber Daya Manusia dan Produktivitas Kerja. Bandung: CV Mandar Maju,

[11]Sedarmayanti. 2017. Manajemen Sumber Daya Manusia. Bandung: Refika Aditama. 